\title{
MOLECULAR CHARACTERISATION \\ OF THRIPS TABACI LINDEMAN, 1889 \\ (THYSANOPTERA: THRIPIDAE) POPULATIONS IN HUNGARY BASED ON THE ITS2 SEQUENCES
}

\author{
Asztéria Almási ${ }^{1}$, István Tóbiás ${ }^{1 *}$, LÁszló Bujdos² and †GÁbor Jenser ${ }^{3}$ \\ ${ }^{1}$ Plant Protection Institute, Centre for Agricultural Research, Hungarian Academy of Sciences \\ H-1525 Budapest, P.O. Box 102, Hungary \\ ${ }^{2}$ Szabolcs-Sz.-B. County Goverment Office of Plant and Soil Conservation Board \\ H-4400 Nyíregyháza, Kótaji út 33, Hungary \\ ${ }^{3}$ Department of Zoology, Hungarian Natural History Museum \\ H-1083 Budapest, Baross u. 13, Hungary \\ *Corresponding author's e-mail: tobias.istvan@agrar.mta.hu
}

Thrips tabaci is comprised of morphologically indistinguishable 'biotypes' or cryptic species with various host ranges, populations propagating by distinct modes and with different virus vector ability. T. tabaci 'communis-type' has wide host range while T. tabaci 'tabacitype' is associated only with tobacco. Since tobacco was introduced to Europe only 500 years ago, we supposed that the differentiation of the T. tabaci 'tabaci-type' population had to begin on another host species that is native to the Palaearctic region. To observe the interaction between host plant preference and molecular characteristics, maximum likelihood tree based on the sequences of the internal transcribed spacer 2 region of the rDNA (ITS2) of Thrips tabaci specimens collected on tobacco, onion, cabbage and distinct weed plants from various locations of Hungary was analysed. According to the results of the phylogenetic study the only common host for Thrips tabaci 'tabaci-type' and Thrips tabaci 'communis-type' was Solanum nigrum. This finding supported our hypothesis that the splitting process of the two main molecular clades could have happened on this solanaceous host species. To compare our results to that of the literature based on cytochrome oxidase I (COI) sequences further investigations with these markers (mitochondrial DNA markers) still needed.

Key words: Thrips tabaci, ITS2 sequence, phylogenetic tree, Solanum nigrum.

\section{INTRODUCTION}

Thrips tabaci Lindeman, 1889 (Thysanoptera, Thripidae) until recently was known as a polyphagous widespread insect pest. As the first reported vector of Tomato spotted wilt virus (TSWV) causes serious epidemics and heavy crop losses worldwide (Pittman 1927). Until the report of Zawirska (1976) it was known as an unambiguous unitary species. Investigating the reason of the variable virus vector activity ZAwIRSKA (1976) established the existence of two biological "types" of T. tabaci: namely "T. tabaci Lindeman (communisTyp Zawirska, 1976) and T. tabaci Lindeman (tabaci-Typ Zawirska, 1976). Ac- 
cording to the establishment of Zawirska, the populations of T. tabaci communis-type do not include males, propagate by thelytokous parthenogenesis, associated with a wide host range, breeding mainly on onion, garlic, leek and cotton and do not able to transmit TSWV. The populations of T. tabaci tabacitype include males, propagate by arrhenotokuos parthenogenesis, associated above all with tobacco and dead-nettle (Lamium sp.) and are effective vectors of TSWV. Zawirska has emphasized that her observations were carried out under Polish climatic conditions. The morphological characters of the adult Thrips tabaci specimens are constant through the world. The two proposed types cannot be distinguished based on morphological characters. The differences in the virus vector capability of the two "biotypes" were confirmed by Wijkamp et al. (1995) and Chatzivassiliou et al. (1999, 2002). Genetic variation based on the mitochondrial COI sequence in relation to the vector competency was linked with the reproduction mode of Thrips tabaci populations by JАСовson et al. (2013a). The existence of two different "biotypes" was confirmed by molecular investigations (JENSER et al. 2001, BRUNNER et al. 2004). It is worthy to mention that these results are regarding specimens collected from tobacco and onion. These investigations confirmed that this morphologically constant species has (at least) three different biotypes and that host plant associated divergence occured. T. tabaci communis-type populations have wide host range. T. tabaci tabaci-type according to Zawirska is associated only with tobacco and dead-nettle populations. Further detailed data regarding the host range are unknown. By reason of the Zawirska's statement the populations of $T$. tabaci breeding on tobacco have been differentiated from the polyphagous $T$. tabaci populations a long time ago. According to the opinion of BRUNNER et al. (2004) this split could be estimated 28 million years ago. Since tobacco was introduced to Europe only 500 years ago, the differentiation of this so called "tobacco associated" population had to begin on another host species that is native to the Palaearctic region.

At the same time we intended to look for further host range of the $T$. tabaci tabaci-type population. To study the very complex interaction/correlation between host plant preference, vector competency, reproduction forms and population genetics, DNA barcoding proves to be a suitable tool. For this purpose, most of the publications deal with mitochondrial COI (and COII) sequence analysis (Brunner et al.2002, 2004, Kobayashi \& Hasegawa 2012, Nault et al. 2014, Toda \& Murai 2007, Jacobson et al. 2013). Internal transcribed spacer 2 region of the rDNA is mostly used at interspecific level (GLover et al. 2010, BucKMAN et al. 2012) but hence Thrips tabaci seems a more complex taxon that comprises of two or more subspecies or even cryptic species (BRUNner et al. 2004), we chose this marker to differentiate the populations according to host plant and to compare our results to the analysis of the COI sequences completed by others. 


\section{MATERIAL AND METHODS}

\section{Sample collection}

Thrips tabaci specimens were collected from tobacco, onion, cabbage and distinct weed plants from the tobacco production region and from other parts of Hungary (Table 1) and identification was confirmed using a compound light microscope. One sample originated from Israel was collected by Dr. David Ben-Yakir and samples from the USA were collected by Dr. József Fail. The 29 thrips specimens were preserved in $96 \%$ ethanol and stored at $-70{ }^{\circ} \mathrm{C}$ until the molecular investigation.

\section{DNA extraction, amplification, cloning and sequencing}

Total genomic DNA was extracted from single thrips individuals using REDExtractN-Ampl ${ }^{\mathrm{TM}}$ Tissue PCR Kit (Sigma) according to the manufacturer's instructions. To amplify the ITS2 sequence CAS5p8Fc and CAS28sB1d primer pair (KIM \& LeE 2008) was used for PCR. PCR was performed using Taq DNA polymerase (Fermentas) in a thermo-cycler (Eppendorf Mastercycler gradient) as follows: initial denaturation at $96^{\circ} \mathrm{C}$ for $4 \mathrm{~min}$, followed by 40 cycles of $95^{\circ} \mathrm{C}$ for $30 \mathrm{sec}$, annealing at $50^{\circ} \mathrm{C}$ for $30 \mathrm{sec}$, extension at $72{ }^{\circ} \mathrm{C}$ for $60 \mathrm{sec}$; final extension at $72{ }^{\circ} \mathrm{C}$ for $10 \mathrm{~min}$. The PCR products were purified using the Gel/PCR DNA Fragments Extraction Kit (Geneaid). Purified PCR products were cloned into CloneJet (Fermentas) or pGEM-T Easy vectors and inserted into Escherichia coli DH $5 \alpha$ competent cells. All cloning steps were based upon standard molecular biology protocols (ХАмвRоок et al. 1989). The recombinant plasmids isolated from selected colonies were sequenced using pJET1.2 forward and reverse primers, the PCR products were sequenced by CAS5p8sFc and CAS28sB1d primers by an automated DNA sequencer (Applied Biosystem Gene Analyzer 3100). Sequences were analyzed with the CLC Sequence Viewer 6.8.1. or MEGA 6.06 program (TAMURA et al. 2007). DNA sequences in the ITS2 region of the thrips specimens were deposited to the GenBank (Table 1). Estimates of evolutionary divergence between ITS2 sequences were conducted using the Kimura 2-parameter model (KImurA 1980). The rate variation among sites was modeled with a gamma distribution (shape parameter $=$ 5.58). The analysis involved 29 nucleotide sequences (see the Electronic Supplement). Codon positions included were $1 \mathrm{st}+2 \mathrm{nd}+3 \mathrm{rd}+$ Noncoding. All positions containing gaps and missing data were eliminated. There were a total of 413 positions in the final dataset. Evolutionary analyses were conducted in MEGA6 (TAmura et al. 2013).

Maximum likelihood (ML) tree was constructed and used to evaluate taxonomic relationships among the tested 29 Thrips tabaci individuals. Bootstrap support for ML trees was assessed using 1000 replicates. Maximum-likelihood tree was composed using TamuraNei model (TAmura et al. 2011) according to MEGA model selection; Thrips urticae was chosen for outgroup species.

\section{RESULTS}

The length of the ITS2 sequences varied between 481-487 bp. Phylogenetic tree of ITS2 sequences of Thrips tabaci specimens collected from different host plants and distinct geographical locations was constructed as shown in Figure 1. 
Table 1. List of Thrips tabaci individuals, host plants, origins, GenBank accession numbers and sample name (see Fig. 1)

\begin{tabular}{|c|c|c|c|}
\hline Host plant & Location $^{1}$ & $\begin{array}{l}\text { GeneBank } \\
\text { acc. no. }\end{array}$ & Sample name \\
\hline \multirow[t]{2}{*}{ Allium cepa } & $\begin{array}{l}\text { Pottersville, New York, } \\
\text { USA }\end{array}$ & JF968504 & Onion USA-1 \\
\hline & & JF968503 & Onion USA-2 \\
\hline Allium porrum & Beg Dagan, Israel & KP216405 & Onion Israel-1 \\
\hline \multirow[t]{3}{*}{ Allium schoenoprasum } & Felcsút & JF968500 & Onion Felcsut-1 \\
\hline & & JF968499 & Onion Felcsut-2 \\
\hline & & JF968505 & Onion Felcsut-3 \\
\hline Asclepias syriaca & Pilismarót & & Asclepias Pilismarot-1 \\
\hline \multirow[t]{4}{*}{ Brassica oleracea } & Tordas & KP216398 & Cabbage Ocsa-1 \\
\hline & Geneva, New York, USA & JF968493 & Cabbage USA-1 \\
\hline & & JF968492 & Cabbage USA-2 \\
\hline & & JF968502 & Cabbage USA-3 \\
\hline Capsella bursa-pastoris & Encsencs ${ }^{*}$ & & Capsella Encsencs-1 \\
\hline \multirow[t]{6}{*}{ Nicotiana tabacum } & Nyíregyháza* & KP216403 & Tobacco Nyiregyhaza-1 \\
\hline & Debrecen* & JF968495 & Tobacco Debrecen-1 \\
\hline & & JF968496 & Tobacco Debrecen-2 \\
\hline & & JF968497 & Tobacco Debrecen-3 \\
\hline & & JF968498 & Tobacco Debrecen-4 \\
\hline & & JF968501 & Tobacco Debrecen-5 \\
\hline \multirow[t]{5}{*}{ Solanum nigrum } & Nagycserkesz ${ }^{*}$ & KP216402 & Snigrum Nagycserkesz-1 \\
\hline & & KP216404 & Snigrum Nagycserkesz-2 \\
\hline & Csengersima & KP216397 & Snigrum Csengersima-1 \\
\hline & Nagykovácsi & KP216396 & Snigrum Nagykovacsi-1 \\
\hline & & KP216399 & Snigrum Nagykovacsi-2 \\
\hline \multirow[t]{2}{*}{ Solanum tuberosum } & Tiszanagyfalu* & KP216407 & Potato Tiszanagyfalu-1 \\
\hline & Keszthely & KP216395 & Potato Keszthely-1 \\
\hline Stellaria media & Szada & KP216406 & Stellaria Szada131-1 \\
\hline \multirow[t]{3}{*}{ Urtica dioica } & Nagykovácsi & KP216394 & Thripsurticaet706-L1.1 \\
\hline & & & $\begin{array}{l}\text { Thripsurticaet706.1 (or- } \\
\text { ganism: Thrips urticae) }\end{array}$ \\
\hline & & & $\begin{array}{l}\text { Thrips sp.T1.2 (organ- } \\
\text { ism: Thrips sp.) }\end{array}$ \\
\hline
\end{tabular}

${ }^{1}$ where country is not indicated means Hungary; ${ }^{*}$ tobacco production region 
The phylogenetic tree was divided into strongly supported (99\% support) two main clades; one of them composed of the tobacco associated $8 \mathrm{~T}$. tabaci individuals. All the tobacco associated clones originated from N. tabacum or

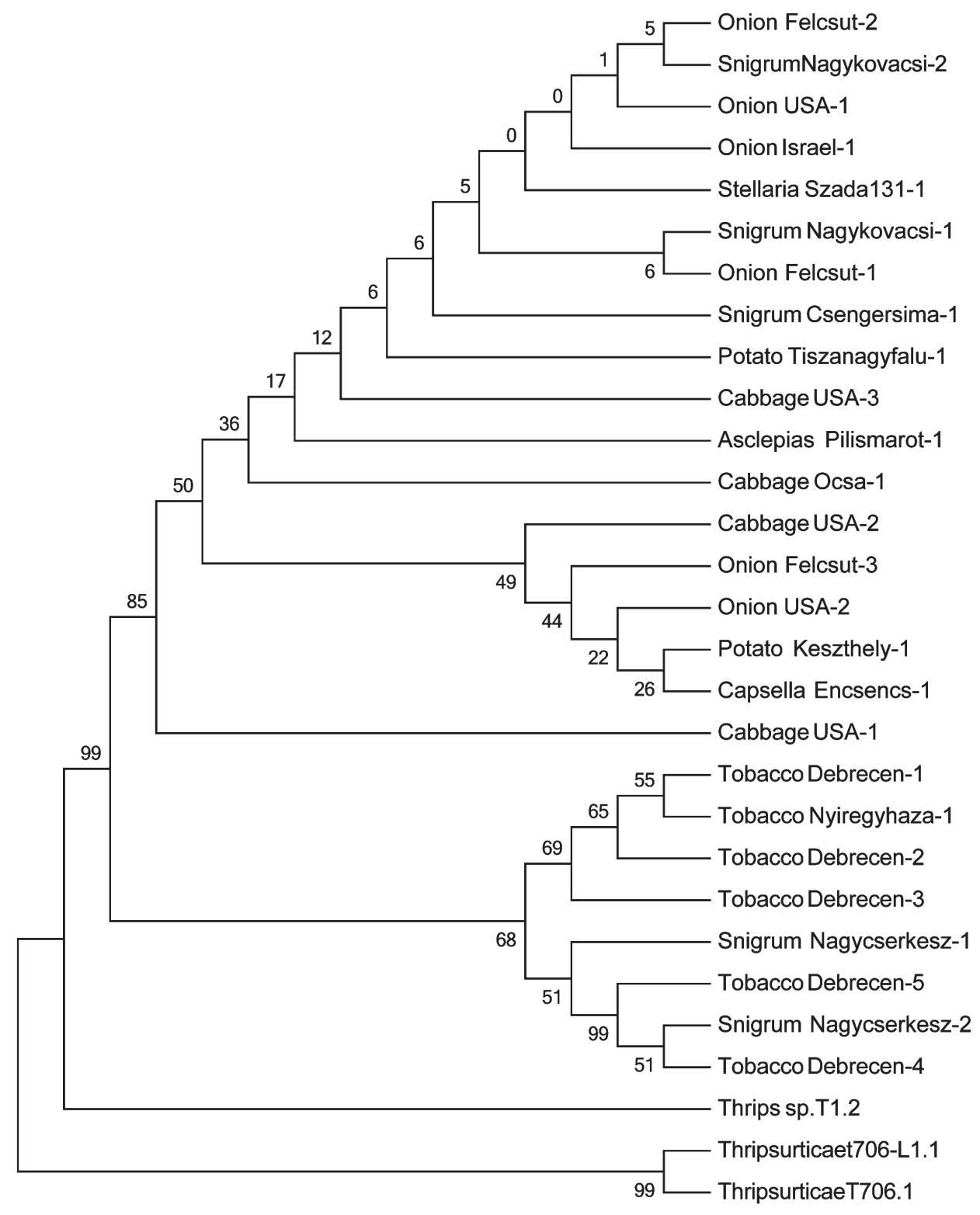

Fig. 1. Maximum likelihood tree constructed from ITS2 sequences of Thrips tabaci specimens collected from different plants and region of Hungary, USA and Israel (see Table 1). 
S. nigrum from the tobacco production region in Hungary. The other clade of the onion associated 18 specimens formed two subclades (support 85\%), one is represented by one specimen (Cabbage USA-1). Out of the other 17 clones 12 could be found in one branch (I) and 5 in another branch (II) (support $50 \%$ ), but the differences were not well supported. Three thrips specimens of $S$. nigrum from this branch originated outside of the tobacco production region belonged to this formerly mentioned branch I composed individuals collected on onion, cabbage, potato from the tobacco production region, Asclepias syriaca, Stellaria media. The other branch II contained individuals collected on cabbage, onion, potato outside the tobacco production region and Capsella bursa-pastoris. Among all the host plants only S. nigrum served host plant for Thrips tabaci in both clades.

\section{DISCUSSION}

Our results gained by phylogenetic tree analysis of ITS2 sequences of Thrips tabaci specimens collected from different host plants showed the same pattern as BRUNNER et al. (2004) observed on phylogenetic analysis of the mtCOI sequences about the molecular distinction of three main clades. In the literature molecular investigations of Thrips tabaci populations focus on the two or three main agricultural host plants, such as tobacco, leek/onion and cabbage. JАсовоо et al. $(2013 a, b)$ analysed the interactions between the molecular characteristics of T. tabaci collected from Allium spp., Brassica spp., Raphanus spp. Secale cereale and vector competency of various TSWV isolates in North Carolina, where T. tabaci does not play a role in TSWV transmission in tobacco (Jenser et al. 2011). Phylogenetic studies concerning different reproductive modes and geographically distinct thrips populations revealed similar tree composition to the host plant preference: thelytokous and arrhenotokous haplotypes divided into two or three main clades (JAcobson et al. 2013, TodA \& Murai 2007, Nault et al. 2014). In our experiments we extended the number of host plant species in order to support our hypothesis that the split between the two main clades or biotypes could have happened by an adapting mechanism to tobacco across an intermediate breeding host that might be a relative taxon of Nicotiana tabacum. Therefore we chose Solanum nigrum as a possible intermediate host and based on our results we found that among the host plant species we have collected Thrips tabaci specimen, from this host plant proved the sole host for both thrips biotypes. BrunNer et al. (2004) estimated the phylogenetic split of the leek-associated and tobacco-associated lineages to 28 million years ago. Hence the nucleotide sequence differences in the hypervariable ITS2 region among closely related species are pronounced, the nucleotide sequence distances (Electronic Supplement) not higher than 0.05 
in our experiment indicate that the phylogenetic division process might have not finished yet, rather it has been still in progress. It can be supposed, that the two taxa are not distinct cryptic species, but more likely biotypes that may have been still differentiating and the evolution of the Thrips tabaci taxon complex is still on progress. The fact that we found a plant species belonging to the Solanaceae family that was the only common host for T. tabaci tabaci-type and T. tabaci communis-type supported our hypothesis that in Hungary the splitting process of the two main molecular clades could have happened on the host species Solanum nigrum. To compare our results to that of the literature based on COI sequences further investigations needed with these markers (mitochondrial DNA markers).

\section{REFERENCES}

Brunner, P. C., Fleming, C. \& Frey, J. E. (2002) A molecular identification key for economically important thrips species (Thysanoptera: Thripidae) using direct sequencing and a PCR-RFLP-based approach. Agricultural and Forest Entomology 4: 127-136. http://dx.doi.org/10.1046/j.1461-9563.2002.00132.x

Brunner, P. C., Chatzivassiliou, E. K., Katis, N. I. \& Frey, J. E. (2004) Host-associated genetic differentiation in Thrips tabaci (Insecta: Thysanoptera), as determined from mtDNA sequence data. Heredity 93: 364-370. http://dx.doi.org/10.1038/sj.hdy.6800512

Chatzivassiliou, E. K., Nagata, T., Peters, D. \& Katis, N. I. (1999) The transmission of tomato spotted wilt tospovirus (TSWV) by Thrips tabaci Lind. (Thysanoptera: Thripidae) populations originating from leek. Plant Pathology 48: 700-706. http://dx.doi. org/10.1046/j.1365-3059.1999.00414.x

Chatzivassiliou, E. K., Peters, D. \& Katis, N. I. (2002) The efficiency by which Thrips tabaci populations transmit Tomato spotted wilt virus depends on their host preference and reproductive strategy. Phytopathology 92: 603-609. http://dx.doi.org/10.1094/ PHYTO.2002.92.6.603

Glover, R. H., Collins, D. W., Walsh, K \& Boonham, N. (2010) Assessment of loci for DNA barcoding int he genus Thrips (Thysanoptera: Thripidae). Molecular Ecology Resources 10: 51-59. http://dx.doi.org/10.1111/j.1755-0998.2009.02723.x

Jacobson A. L., Bоотн W., Vargo E. L. \& Kennedy G. G. (2013a) Thrips tabaci population genetic structure and polyploidy in North Carolina in relation to competency as a vector of Tomato spotted wilt virus. PLoS One. 8(1): e54484. http://dx.doi.org/10.1371/ journal.pone.0054484

Jacobson, A. L. \& Kennedy, G. G. (2013b) Specific insect-virus interactions are responsible for variation in competency of different Tomato spotted wilt virus isolates. PLoS One 8(1): e54567. http://dx.doi.org/10.1371/journal.pone.0054567

Jenser, G., SzénÁsi, Á., TörJéK, O., Gyulai, G., Kiss, E., Heszky, L. \& Fail, J. (2001) Molecular polymorphism between population of Thrips tabaci Lindeman (Thysanoptera: Thripidae) propagating on tobacco and onion. Acta Phytopathologica et Entomologica Hungarica 36: 365-368. http://dx.doi.org/10.1556/APhyt.36.2001.3-4.17 
Jenser, G., Almási, A., Fail, J. \& Tóbiás, I. (2011) Differences in the vector efficiency of Thrips tabaci in Europe and North America. Acta Phytopathologica et Entomologica Hungarica 46: 311-317. http://dx.doi.org/10.1556/APhyt.46.2011.2.15

KIM, H. \& LeE, S. (2008) Molecular systematics of the genus Megoura (Hemiptera: Aphididae) using miotochondrial and nuclear DNA sequences. Molecules and Cells 25: 510-522.

KimurA, M. (1980) A simple method for estimating evolutionary rate of base substitutions through comparative studies of nucleotide sequences. Journal of Molecular Evolution 16: 111-120. http://dx.doi.org/10.1007/BF01731581

Kobayashi, K. \& Hasegawa, E. (2012) Discrimination of reproductive forms of Thrips tabaci (Thysanoptera: Thripidae) by PCR with sequence specific primers. Journal of Economic Entomology 105: 555-559. http://dx.doi.org/10.1603/EC11320

Nault, B. A., KaIn, W. C. \& WANG, P. (2014) Seasonal changes in Thrips tabaci population structure in two cultivated hosts. PLoS ONE 9: e101791. http://dx.doi.org/10.1371/ journal.pone.0101791

Pittman, H. A. (1927) Spotted wilt of tomatoes. Journal of Australian Council for Science and Industrial Research 1: 74-77.

Sambrook, J., Fritsch, E. F. \& Maniatis, T. (1989) Molecular Cloning. A Laboratory Manual. 2nd ed. Cold Spring Harbor Laboratory, Cold Spring Harbor, New York.

Tamura, K., Dudley, J., Nei, M. \& Kumar, S. (2007) MEGA4: Molecular evolutionary genetics analysis (MEGA) software version 4.0. Molecular Biology and Evolution 24: 15961599. http://dx.doi.org/10.1093/molbev/msm092

Tamura, K., Peterson, D., Peterson, N., Stecher, G., Nei, M. \& Kumar, S. (2011) MegA5: molecular evolutionary genetics analysis using maximum likelihood, evolutionary distance, and maximum parsimony methods. Molecular Biology and Evolution 28: 2731-2739. http://dx.doi.org/10.1093/molbev/msr121

Tamura, K., Stecher, G., Peterson, D., Filipski, A. \& Kumar, S. (2013) MEGA6: Molecular Evolutionary Genetics Analysis version 6.0. Molecular Biology and Evolution 30: 2725-2729. http://dx.doi.org/10.1093/molbev/mst197

Toda, S. \& Komazaki, S. (2002) Identification of thrips species (Thysanoptera: Thripidae) on Japanese fruit trees by polymerase chain reaction and restriction fragment length polymorphism of the ribosomal ITS2 region. Bulletin of Entomological Research 92: 359-363. http://dx.doi.org/10.1079/BER2002177

Toda, S. \& MuraI, T. (2007) Phylogenetic analysis based on mitochondrial COI gene sequences in Thrips tabaci Lindeman (Thysanoptera: Thripidae) in relation to reproductive forms and geographic distribution. Applied Entomology and Zoology 42: 309316. http://dx.doi.org/10.1303/aez.2007.309

Westmore, G. C., Poke, F. S., Allen, G. R. \& Wilson, C. R. (2013) Genetic and host-associated differentiation within Thrips tabaci Lindeman (Thysanoptera: Thripidae) and its links to Tomato spotted wilt virus-vector competence. Heredity 111: 210-215. http:// dx.doi.org/10.1038/hdy.2013.39

Wijkamp, I., Almarza, N., Goldbach, R. \& Peters, D. (1995) Distinct levels of specificity in thrips transmission of tospoviruses. Phytopathology 85: 1069-1074. http://dx.doi. org/10.1094/Phyto-85-1069

ZAwiRsKA, I. (1976) Untersuchungen über zwei biologische Typen von Thrips tabaci Lind. (Thysanoptera, Thripidae) in der VR Polen. Archiv für Phytopathologie und Pflanzenschutz 12: 411-422. http://dx.doi.org/10.1080/03235407609431780

Received January 8, 2015, accepted October 28, 2015, published May 6, 2016 